\title{
The effect of logistics service quality on customer satisfaction and repurchase intention: focusing on company size as a moderator
}

\author{
Yong-Ock Lee* and Minsung Kim ${ }^{* *}$
}

\begin{abstract}
There are many studies supporting that logistics service quality affects on customers satisfaction and these satisfied customers have a strong repurchase intention in consumer products. However, a few studies involving Industrial products examined these relationships. Therefore, the main purposes of this study are (1) to empirically examine logistics service factors influencing on the customers' satisfaction and repurchase in industrial purchasing, (2) to clarify the differences of service factors between customers satisfaction and repurchase in industrial purchasing process, and (3) to analyze the influence of these factors on the customers' satisfaction depending on the size of company. As a result of an analysis of survey data, this study found the followings. (1) the factors affect customer satisfaction and the factors affect repurchase intention are different from each other; 5 factors (timeliness, order quality, personnel intimacy, personnel quality, order release quantities) for customer satisfaction and 6 factors (timeliness, order period, personnel quality, order quality, information factor, order release quantities) for repurchase intention. (2) the relationship between order release quality factor and customer satisfaction was differ depending on the company size. The large companies showed a stronger relationship than the smaller company did. (3) the positive linear relationship between customer satisfaction and repurchase intention was identified also in industrial purchasing.
\end{abstract}

Keywords: industrial marketing, logistics service quality, logistics service quality dimensions, customer satisfaction, repurchase intention.

\footnotetext{
Submission Date: 28/12/2007_Revision Date: 05/06/2008_ Acceptance date: 09/06/2008

* Graduate Student, Inha University, 253 Yonghyun-dong, Nam-gu, Incheon 402-751, Korea

${ }^{*}$ Corresponding Author, Assistant Professor, Inha University, 253 Yonghyun-dong, Nam-gu, Incheon 402-751, Korea. Email:minskim@inha.ac.kr
} 


\section{Introduction}

The term "Globalization," which has been used to describe recent world economy, infers "Global competition." That is, companies began to compete not only with local competitors but also with world-wide competitors, as an ideological dispute among nations was lessened. However, this is also an opportunity as well as a threat to the companies, because they should operate their business in this extreme competition, and at the same time, they can expand their market to world wide level.

Then, what could be the key success factors in this competitive environment? Competitive price and product/service quality have been the most important factors for successful companies, however, continuous development in manufacturing made the price and quality differentiation marginal. The next differentiation point that companies focused on is logistics services. Companies are beginning to understand the importance of logistics service, and they emphasize the value of customer oriented logistics service on the customer satisfaction (Bowersox, et al., 1992).

The reasons why logistics services are getting more highlight could be; first, logistics cost for companies are increasing year by year, second, customers' service demand has been diverse, specialized, and heightened, so that customer service should be improved more, and third, logistics service area, such as packaging, warehousing, and transportation, has been greatly improved with the development of information technology. In this regard, logistics service became one of strategic assets in global business environment and most of the companies are trying to define logistics service as a differentiation factor.

So far, the studies on the relationship between logistics service and customer satisfaction has been done in retail setting, including retailers and end-users. However, the similar studies on industrial buyers and sellers have been limited, in spite of the importance of logistics service in industrial purchasing process. Therefore, the purpose of this study is to explore the important logistics service quality in relation to customer satisfaction and customer repurchase intention, to examine the relationships among logistics service quality, customer satisfaction, and customer repurchase intention, and to investigate the role of company size as a moderator of the relationships. By performing the study in industrial purchase context (especially, chemical raw material purchase), this study intended to suggest effective ways of improving logistics service quality for industry purchase process.

\section{Research background}

This section is composed of four parts. First of all, the concept of logistics service quality is introduced and defined. Secondly, factors or dimensions of logistics service quality is identified based on the previous literature dealing with general service quality or logistics service quality, so that this part will answer the question of what factors constitute logistics service quality. Then, previous studies dealing with customer satisfaction and different characteristics of customer 
management between industrial market and consumer market are reviewed and summarized. Lastly, studies on customers' repurchase behavior are examined.

\subsection{Logistics service quality}

Logistics is defined as the comprehensive process for end-users to get products/services, including raw materials or part supplies, manufacturers' production, and product flows through intermediaries (Ballou, 1985). In this logistics process, service provision is essential since various participants are connected and networked (TH Kim and SA Moon, 1998). As logistics process is developed and emphasized, the concept of logistics service has been expanded to provide; (1) first level satisfaction by delivering the ordered product or service, (2) second level satisfaction by providing after-sale service for maintenance and technical updating, and (3) third level satisfaction by dealing with waste and better environment. In other words, logistics service should be defined as activities creating economic utility, such as possession, time, and location utilities, in logistics process of products/services between purchaser and seller. Based on this definition, product/service availability and timely delivery are especially important in logistics service.

Like researchers define logistics in various style, logistics service is also defined in diverse ways, especially in terms of the scope and contents of logistics services. Whereas the early definitions were made in view of suppliers, the recent definitions are trying to include the customers' point of view.

Heskett (1962) insisted that the ideal logistics service should consider physical aspect, such as transportation and warehousing, as well as service supply including timely delivery and higher order fulfillment. On the other hand, Perreault and Russ (1976) defined the customer service as "a package of interdependent activities between customers and suppliers who provides time and location utilities and guarantees form utilities." This implies that logistics service is a mechanism to preserve product availability. Moreover, Lalond and Zinszer (1976) suggested that logistics service is a business philosophy controlling and managing all factors interacting between predetermined cost and services. More recently, Lambert and Stock (1982) showed more market-oriented view and defined logistics service as demand creating activities and insisted that logistics service performance should be measured by the level of logistics system's contribution on the creation of time and location utilities.

Consequently, logistics service is activities of creating time and location utility in the process of delivering ordered product/service from suppliers to customers by observing terms of trade. Also, logistics service is closely related to market share and profit increase, so it should be perceived as one of marketing strategies (Lambert and Zemke, 1982). In this regard, providing effective logistics service necessarily include understanding of customers' service demand differences, and this should be used in differential strategy in business.

\subsection{Logistics service quality dimensions}

Theoretically, the sub-dimensions of logistics service should include all activities and functions needed to accomplish the purpose of whole logistics process. That is, all activities and 
functions related to provide form, time, and location utilities. Logistics itself was perceived as providing competitive values by fulfilling customers' service demand in volatile business environment, and the customers' service demand is fulfilled by several factors, such as product utility, time, delivery, and order convenience, etc. (Arthur D. Little, Inc, and Pennsylvania State University, 1991). Previous studies suggested several service factors with a slight difference among researchers (Table 1), but they identified timely, adequate, and reliable services as common logistics service dimensions (JD Kim, 2002).

Table 1

Logistics service factors

\begin{tabular}{|c|c|}
\hline Researcher & Logistics Service Factors \\
\hline Perreault (1973) & $\begin{array}{l}\text { order process, average delivery time, delivery time change, urgent service, return } \\
\text { policy, order tracking, order fulfillment, order methods }\end{array}$ \\
\hline $\begin{array}{c}\text { La londe } \\
\text { \& Zinszer (1976) }\end{array}$ & factors before the transaction, during the transaction, after the transaction \\
\hline Gilmour (1982) & $\begin{array}{l}\text { product usability, after-sale service and return, order convenience, effective } \\
\text { communication on order and inquiry, technical capability of salespeople, delivery } \\
\text { time, reliability of delivery, equipment demonstration, information availability }\end{array}$ \\
\hline Christopher (1983) & $\begin{array}{l}\text { order cycle time, consistency and reliability of delivery, stock availability, order } \\
\text { limit, delivery time and flexibility, claim process, product condition }\end{array}$ \\
\hline $\begin{array}{l}\text { Jacson, Keith, } \\
\text { Burdick (1986) }\end{array}$ & $\begin{array}{l}\text { consistency of delivery, product availability, stock, order cycle time, cooperation, } \\
\text { order information }\end{array}$ \\
\hline $\begin{array}{l}\text { Mentzer, Gomes, } \\
\text { Krapfel (1989) }\end{array}$ & product availability, timeliness, order quality \\
\hline $\operatorname{Marr}(1990)$ & $\begin{array}{l}\text { product availability, low error rate, communication organization, return policy, } \\
\text { frequency of delivery, reliability of delivery, product service }\end{array}$ \\
\hline $\begin{array}{c}\text { Pisharodi } \\
\text { \& Langley (1990) }\end{array}$ & $\begin{array}{l}\text { product availability, order cycle time, capability of channel system, information } \\
\text { from channel system }\end{array}$ \\
\hline $\begin{array}{l}\text { Coyle,Bardi, } \\
\text { Langley (1992) }\end{array}$ & time, reliability, communication, convenience \\
\hline $\begin{array}{l}\text { Daugherty, Stank, } \\
\text { Ellinger (1998) }\end{array}$ & $\begin{array}{l}\text { delivery fulfillment rate, rate of order-shipment completion, consistency of order } \\
\text { cycle, length of order cycle, timely delivery, frequency of delivery, communication, } \\
\text { invoice accuracy, shipping notice, use of preferred carrier, customized service }\end{array}$ \\
\hline $\begin{array}{c}\text { Aronld Maltz, } \\
\text { Elloit Maltz (1998) }\end{array}$ & responsiveness, order cycle time, timely delivery, stock availability \\
\hline
\end{tabular}

Among other studies, Mentzer et al. (1989) suggested that there are two broad categories in 
service delivery, one is marketing customer service and the other is physical distribution service, PDS) being composed of availability, timeliness, and quality. They understood that these two categories compensate each other, and proposed integrated framework for customer service. This point of view combines company's marketing activities and logistics activities.

More recently, Mentzer et al. (2001) performed a study about the structure of overall concept of logistics service quality (LSQ) and they identified 9 components of LSQ, then found that these components could be used to segment customer by industry.

Based on the previous studies and identified LSQ components by Mentzer et al. (2001), this study adopted 9 LSQ components and modified to fit industrial logistics service context. More detailed description on 9 LSQ components are summarized in Table 2.

Table 2

Logistics service quality components by Mentzer, Flint, and Hult (2001)

\begin{tabular}{|c|c|}
\hline Components & Descriptions \\
\hline Personnel Contact Quality & $\begin{array}{l}\text { - Contact personnel makes an effort to understand my situation } \\
\text { - Problems are resolved by the contact personnel } \\
\text { - The product knowledge/experience of contact personnel is adequate }\end{array}$ \\
\hline Order Release Quantities & $\begin{array}{l}\text { - Requisition quantities are not challenged } \\
\text { - Difficulties never occur due to maximum release quantities } \\
\text { - Difficulties never occur due to minimum release quantities }\end{array}$ \\
\hline Information quality & $\begin{array}{l}\text { - Catalog information is available } \\
\text { - Catalog information is adequate }\end{array}$ \\
\hline Ordering procedures & $\begin{array}{l}\text { - Requisitioning procedures are effective } \\
\text { - Requisitioning procedures are easy to use }\end{array}$ \\
\hline Order Accuracy & $\begin{array}{l}\text { - Shipments rarely contain the wrong items } \\
\text { - Shipments rarely contain an incorrect quantity } \\
\text { - Shipments rarely contain substituted items }\end{array}$ \\
\hline Order Condition & $\begin{array}{l}\text { - Material received from logistics company is undamaged } \\
\text { - Material received direct from vendors in undamaged } \\
\text { - Damage rarely occurs as a result of the transport mode of carrier }\end{array}$ \\
\hline Order Quality & $\begin{array}{l}\text { - Substituted items sent by logistics company work fine } \\
\text { - Products ordered from logistics company meet technical requirements } \\
\text { - Equipment and/or parts are rarely nonconforming }\end{array}$ \\
\hline Order Discrepancy Handling & $\begin{array}{l}\text { - Correction of delivered quality discrepancies is satisfactory } \\
\text { - The report of discrepancy process is adequate } \\
\text { - Response to quality discrepancy report is satisfactory }\end{array}$ \\
\hline Timeliness & $\begin{array}{l}\text { - Time between placing requisition and receiving delivery is short } \\
\text { - Deliveries arrive on the date promised } \\
\text { - The amount of time a requisition is on back-order is short }\end{array}$ \\
\hline
\end{tabular}




\subsection{Customer satisfaction}

The definition of customer satisfaction is relatively agreed among researchers. Oliver (1980) defined customer satisfaction as "comprehensive psychological state when customers' expectation before the purchase and customers' perceived reward after the purchase are combined." According to American Marketing Association (AMA), customer satisfaction happens when customers expected needs/wants are fulfilled or over-fulfilled, and customer dissatisfaction happens when customers' expectation is not met.

Most of the previous studies on customer satisfaction have been done in consumer markets by analyzing individual customer. Customer satisfaction studies on industrial market context has been relatively limited, however, more researchers are dealing with customer satisfaction management in industrial market recently.

Cardozo (1965) who initiated the application of customer satisfaction concept in marketing area, introduced customer satisfaction as measuring the difference between customer expectation of company service and customer perceived company service. And later, measuring customer satisfaction has been more elaborated.

In industrial market, customer relationship is more emphasized than simple customer satisfaction, because industrial market requires longer-term and more complex customer relationship (Hunt MD \& Speh, 1992). Since suppliers and customers are influencing each other, customer oriented service provision is necessary as well as customers should be considered as partners, not passive entities.

Gummesson (1994) investigated customer characteristics between industrial market and consumer market (Table 3), and suggested that customer satisfaction in industrial market should be understood as relationship-oriented rather than transaction-oriented.

Table 3

Customer characteristics - industrial market vs. consumer market

\begin{tabular}{l|c|c}
\hline \multicolumn{1}{c|}{ Characteristics } & Industrial market & Consumer market \\
\hline \hline Number of customers & Few & Many \\
Strength of relationship & Strong & Weak \\
Number of customer contact & Many & Few \\
Switching cost & High & Low \\
Purchase quantity & Large & Small \\
Information tracking & Easy & Difficult \\
Knowledge transfer amount & Large & Small \\
\hline
\end{tabular}

As shown in table 3, customer characteristics between industrial and consumer markets are fairly different, so customer management in industrial market should be different from that in 
consumer market. For example, since the number of customers is few and the number of customer contacts is many for industrial market, customer relationship development requires organization wide effort to figure out customers needs.

\subsection{Repurchase intention}

In general, customer perceived satisfaction and dissatisfaction affects on customers' purchase intention. When satisfied customers repurchase, sales increased without additional investment and enjoys higher profit. Especially when customers have repurchase intention, they are more likely to be loyal customers, and then company is able to make a based for long-term demand.

Newman and Werbel (1973) showed that dissatisfied customers are less likely to repurchase than satisfied customers, and the study by Oliver (1986) supported the hypothesis that customer satisfaction influence on customers' positive attitude toward the purchased product and then positively influence on repurchase intention.

Later, Oliver and Swan (1989) empirically found that customer satisfaction and after purchase attitude have positive relationship with repurchase intention. Also, they identified that customers who expressed their complaint are more likely to repurchase even when the complaint was not resolved well, than customers who do not express their complaint. This implies that company should make a route to express complaint for customers, in order not to lose their customers to other brands.

On the other hand, Geva and Goldman (1999) adopted cognitive dissonance theory, and showed that customer could have weak repurchase intention even though they are satisfied. This is based on the fact that satisfaction reflects the need to justify the action previously done, whereas repurchase intention reflects the lessons learned from purchase experience, so two constructs might not have a significant relationship. Their study is valued since they applied cognitive dissonance to repurchase intention, but the relationship between the two has not been empirically tested.

Lele and Sheth (1991) added the concept of price sensitivity, and suggested that the degree of influence of satisfaction on repurchase intention is reduced as customers are price sensitive. Similarly, Rust and Jahorik (1993) showed that the relationship between satisfaction and repurchase intention is getting weaker as time goes by.

\section{Methodology}

In this section, the variables included in this study are introduced first. Secondly, the research framework and each hypothesis are presented. Then statistical methods involved in the hypotheses testing will be summarized in the last part.

\subsection{Variables}

\section{Logistics service quality (LSQ)}


Based on the previous studies on LSQ, 18 items measuring LSQ were selected and listed in Table 4. Each item was asked separately for customer satisfaction and repurchase intention, in order to test the similarity or dissimilarity of LSQ dimensions for customer satisfaction and for repurchase intention. All items were prepared as 5 point likert scale.

Table 4

LSQ measurement

\begin{tabular}{|c|c|}
\hline Variables & Description \\
\hline $\begin{array}{l}\text { Knowledge and experience of } \\
\text { service personnel }(\mathrm{S} 1, \mathrm{R} 1)^{1}\end{array}$ & Degree of service personnel's experience and knowledge about work \\
\hline $\begin{array}{c}\text { Cooperation of service } \\
\text { personnel }(\mathrm{S} 2, \mathrm{R} 2)\end{array}$ & $\begin{array}{l}\text { Degree of service personnel's appreciation of customers and cooperative } \\
\text { attitude }\end{array}$ \\
\hline $\begin{array}{l}\text { Friendliness of service } \\
\text { personnel }(\mathrm{S} 3, \mathrm{R} 3)\end{array}$ & Individual closeness between service personnel and customers \\
\hline Order release quantity $(\mathrm{S} 4, \mathrm{R} 4)$ & Maximum or minimum of order quantity \\
\hline Back order quantity (S5, R5) & Degree of back-order \\
\hline $\begin{array}{l}\text { Timely information provision } \\
(\mathrm{S} 6, \mathrm{R} 6)\end{array}$ & Degree of providing timely transaction information to customers \\
\hline $\begin{array}{l}\text { Adequate information } \\
\text { provision }(\mathrm{S} 7, \mathrm{R} 7)\end{array}$ & Degree of providing adequate transaction information to customers \\
\hline $\begin{array}{l}\text { Convenient ordering process } \\
(\mathrm{S} 8, \mathrm{R} 8)\end{array}$ & Degree of ordering process convenience for customers \\
\hline Ordering accuracy $(\mathrm{S} 9, \mathrm{R} 9)$ & Degree of accurate shipment of ordered items \\
\hline Ordering quality (S10, R10) & Degree of problem happening in ordered items during the delivery \\
\hline $\begin{array}{l}\text { Consistency of quality (S11, } \\
\text { R11) }\end{array}$ & Degree of shipping the right items \\
\hline $\begin{array}{l}\text { Order discrepancy handling } \\
(\mathrm{S} 12, \mathrm{R} 12)\end{array}$ & Degree of resolving the complaints in terms of time and adequacy \\
\hline Timely delivery (S13, R13) & Degree of delivering no later than the data customers wanted \\
\hline Average order cycle (S14, R14) & Degree of length of time between order and delivery \\
\hline $\begin{array}{c}\text { Consistency of order cycle } \\
(\mathrm{S} 15, \mathrm{R} 15)\end{array}$ & Degree of consistency of length of time between order and delivery \\
\hline $\begin{array}{l}\text { Responsiveness to urgent order } \\
\text { (S16, R16) }\end{array}$ & Degree of quickly managing urgent order \\
\hline $\begin{array}{l}\text { Accuracy of shipment record } \\
\text { (S17, R17) }\end{array}$ & Degree of accuracy of reporting item lists and quantity \\
\hline $\begin{array}{l}\text { Timely delivery of shipment } \\
\text { record }(\mathrm{S} 18, \mathrm{R} 18)\end{array}$ & $\begin{array}{l}\text { Degree of timely delivery of shipment record before item is actually } \\
\text { delivered }\end{array}$ \\
\hline
\end{tabular}

${ }^{1}$ In variable names (S1, R1), S stands for LSQ variables for customer satisfaction, and R stands for LSQ variables for repurchase intention. 


\section{Satisfaction}

Customer satisfaction was measured using two items; (1) evaluation of overall performance of logistics company, and (2) degree of satisfaction with logistics company services. Both items are expressed as 5 point Likert scale.

\section{Repurchase intention}

Customers' repurchase intention was measured by using three items; (1) repurchase intention with current logistics company, (2) degree of difficulty perception if the relationship with current logistics company is ended immediately, and (3) how importantly perceive the relationship with current logistics company. Like other measurement items, these three also prepared as 5 point Likert scale.

\section{Company size: moderator}

As a moderator, company size was measured by asking the number of companies' full time employee. The question was prepared by multiple choice with 6 choices; (1) less than 10 people, (2) between 10 and 50 people, (3) between 50 and 100 people, (4) between 100 and 200 people, (5) between 200 and 300 people, and (6) more than 600 people.

\subsection{Research framework and hypotheses}

Research framework incorporating the relationships among logistics service quality, customer satisfaction, repurchase intention, and company size as a moderator was constructed and presented in figure 1. Specific hypotheses are as follows;

Hypothesis 1. Logistics service quality will affect on customer satisfaction.

Hypothesis 2. Logistics service quality will affect on repurchase intention

Hypothesis 3 . There will be differences in logistics service quality factors affecting on customer satisfaction and repurchase intention.

This is based on the differences in characteristics between satisfaction and repurchase intention. Since satisfaction is an individual feeling of respondents, satisfaction will be more influenced by service personnel factors among other LSQ factors. On the other hand, repurchase is an organization wide activities, not an individual process, so more objective factors, such as consistency of quality or timeliness, will influence on repurchase intention.

Hypothesis 4. LSQ factors affecting on customer satisfaction will be different depending on company size.

This is based on the differences in the characteristics of large company and small company. In 
general, small companies are more concerned on the operating cost, so they will focus more on factors related to reducing logistics cost for evaluating their satisfaction level. However, large companies will consider other service factors (e.g. consistency of quality, order release quantity) more than only focusing on cost factors.

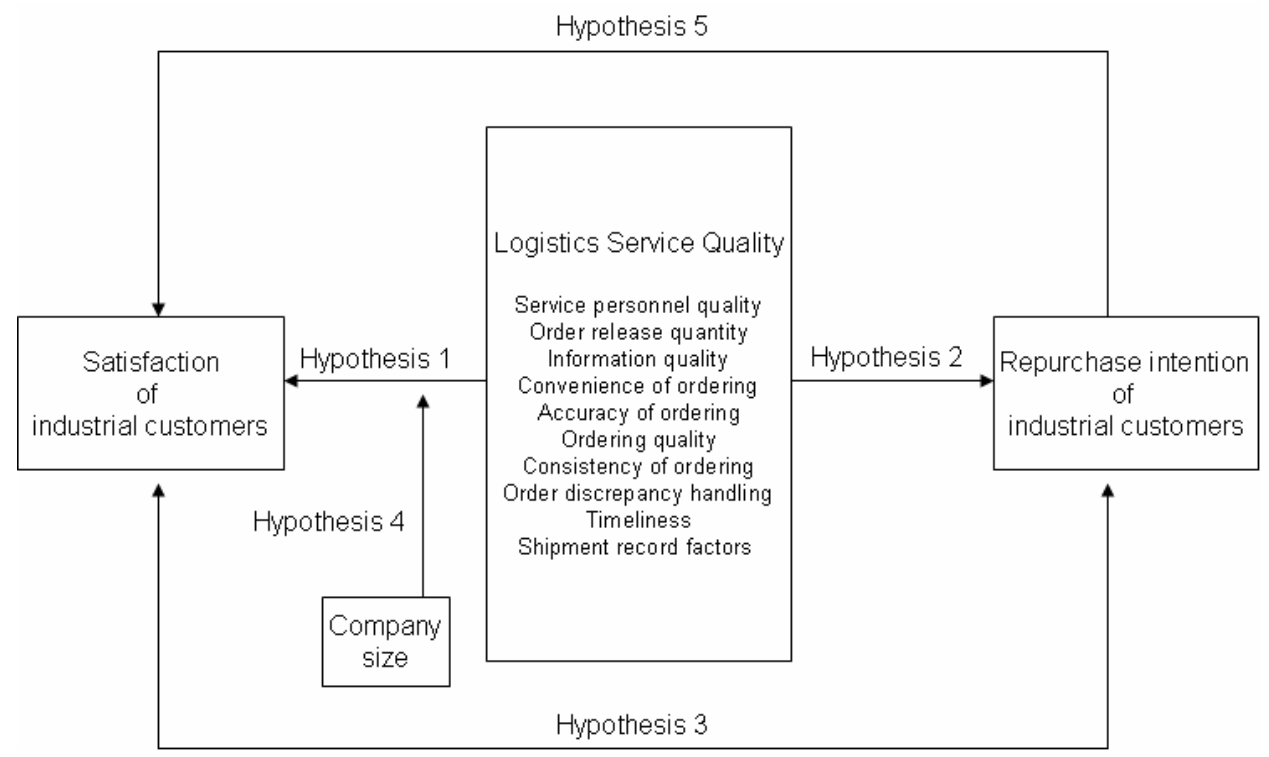

Figure 1. Research framework and hypotheses

Hypothesis 5. Customer satisfaction and repurchase intention will have a positive linear relationship.

This relationship has been empirically tested and confirmed in consumer market, but it should be meaningful to test in industrial market context.

\subsection{Statistical methodology}

Most of all, in order to identify the sub dimensions of LSQ, exploratory factor analysis was performed with 18 LSQ items, then the identified LSQ factors were named and used for further analysis. Also, regression analysis was performed to test the relationships between LSQ and customer satisfaction, between LSQ and repurchase intention, and between customer satisfaction and repurchase intention. The test of moderating effect of company size in the relationship between LSQ and customer satisfaction was performed by using independent t-test. 


\section{Analysis and findings}

\subsection{Survey instrument and data collection}

The sample for this study was defined as manufacturers and wholesalers who purchase chemical raw materials. In order to preserve adequate variability, survey was distributed across different product categories, such as medical products, cosmetics, pesticides, electronics, and beverages.

The respondents of the survey were one representative of purchase department of the company. Total 80 questionnaires were initially distributed and 59 usable survey data was returned and used for the analysis.

Specific questions in survey includes 18 LSQ items, 2 satisfaction items, and 3 repurchase intention items, as well as items about firmography (company sales, size, respondents age, work history, etc.).

As a result of the descriptive analysis of firmograpy, 66.1\% manufacturers and $33.9 \%$ wholesalers are identified in the sample. In terms of the age of the company, companies of 20 years or more was $55.9 \%$ of the sample, and 5 to 10 years old companies account for $22 \%$ of the sample. The analysis of company sales identified that $64.4 \%$ of the company scored more than 50 billion won, implying that most of the company in this sample operate strong business. In terms of the company size, companies with 300 and more employees account for $44.1 \%$, the largest portion in the sample. The result of the analysis was summarized in Table 5.

Table 5

Descriptive analysis of sample firmography

\begin{tabular}{c|c|c|c}
\hline Variables & Categories & Numbers & Percent (\%) \\
\hline \hline \multirow{2}{*}{ Business category } & Manufacturing & 39 & 66.1 \\
& Wholesaling & 20 & 33.9 \\
\hline \multirow{3}{*}{ Age of the company } & Less than 10 yrs & 17 & 28.8 \\
& Between 10-20 yrs & 9 & 15.3 \\
& More than 20 yrs & 33 & 55.9 \\
\hline \multirow{3}{*}{ Size of the company (number of } & Less than 10 & 8 & 13.6 \\
employees) & Between 10-100 & 12 & 16.4 \\
& Between 101-300 & 13 & 22.1 \\
& More than 300 & 26 & 44.1 \\
\hline \multirow{3}{*}{ Company sales in 2006 } & Less than 10 billion & 13 & 22.1 \\
& Between 10-50 billion & 8 & 13.6 \\
& More than 50 billion & 38 & 64.4 \\
\hline
\end{tabular}




\subsection{Hypothesis testing}

\section{Identifying dimensions of LSQ}

To identify LSQ dimensions for customer satisfaction and repurchase intention, separately, two individual exploratory factor analysis (EFA) were performed with principal component analysis as an extraction method and quartimax rotation as a rotation method.

As shown in Table 6, EFA result for LSQ factors related to customer satisfaction identified 5 factors; Timeliness, Service quality consistency, Closeness with personnel, Personnel quality, and Order release quantity. All five factoes explained about $64 \%$ of total variance.

Table 6

Rotated factor components of LSQ for customer satisfaction

\begin{tabular}{|c|c|c|c|c|c|}
\hline & $\begin{array}{l}\text { Timeline } \\
\text { ss }\end{array}$ & $\begin{array}{c}\text { Service } \\
\text { quality } \\
\text { consistency }\end{array}$ & $\begin{array}{l}\text { Closeness } \\
\text { with } \\
\text { personnel }\end{array}$ & $\begin{array}{l}\text { Personnel } \\
\text { quality }\end{array}$ & $\begin{array}{c}\text { Order } \\
\text { release } \\
\text { quantity }\end{array}$ \\
\hline $\begin{array}{l}\text { Timely delivery of shipment } \\
\text { record }\end{array}$ & 0.815 & -0.102 & 0.115 & 0.089 & 0.133 \\
\hline Accuracy of shipment record & 0.774 & 0.230 & -0.025 & 0.057 & -0.093 \\
\hline Average order cycle & 0.663 & 0.020 & -0.088 & 0.398 & 0.375 \\
\hline Timely delivery & 0.652 & 0.353 & 0.129 & -0.110 & 0.020 \\
\hline Consistency of order cycle & 0.649 & 0.050 & -0.007 & 0.064 & 0.323 \\
\hline Ordering quality & 0.633 & 0.330 & 0.291 & -0.182 & -0.108 \\
\hline Consistency of quality & 0.179 & 0.804 & 0.158 & -0.035 & -0.266 \\
\hline Adequate information provision & 0.231 & 0.704 & -0.012 & 0.106 & 0.168 \\
\hline Responsiveness to urgent order & 0.315 & 0.639 & -0.099 & 0.053 & 0.052 \\
\hline Timely information provision & 0.023 & 0.565 & 0.183 & 0.288 & 0.277 \\
\hline $\begin{array}{c}\text { Friendliness of service } \\
\text { personnel }\end{array}$ & 0.106 & 0.262 & 0.743 & 0.209 & -0.252 \\
\hline Convenient ordering process & 0.300 & -0.097 & 0.713 & 0.075 & 0.312 \\
\hline Ordering accuracy & 0.453 & 0.355 & 0.532 & -0.047 & 0.018 \\
\hline $\begin{array}{c}\text { Cooperation of service } \\
\text { personnel }\end{array}$ & 0.187 & 0.112 & 0.075 & 0.820 & -0.141 \\
\hline
\end{tabular}




\begin{tabular}{|c|c|c|c|c|c|}
\hline $\begin{array}{c}\text { Knowledge and experience of } \\
\text { service personnel }\end{array}$ & -0.176 & 0.436 & 0.272 & 0.544 & 0.234 \\
\hline Order discrepancy handling & 0.449 & 0.343 & 0.062 & 0.493 & -0.239 \\
\hline Back order quantity & 0.360 & 0.044 & 0.094 & -0.071 & 0.662 \\
\hline Order release quantity & 0.254 & 0.373 & -0.094 & -0.108 & 0.555 \\
\hline $\begin{array}{l}\text { Rotation sum of squared } \\
\text { loadings }\end{array}$ & 3.903 & 2.833 & 1.636 & 1.596 & 1.501 \\
\hline$\%$ of variation & 21.682 & 15.740 & 9.092 & 8.865 & 8.342 \\
\hline
\end{tabular}

On the other hand, EFA result for LSQ factors related to repurchase intention identified 6 factors; Timeliness, Order cycle consistency, Personnel quality, Service quality consistency, Information provision, Order release quantity (Table 7). And these 6 factors explained about $70 \%$ of the total variance.

Table 7

Rotated factor components of LSQ for repurchase intention

\begin{tabular}{|c|c|c|c|c|c|c|}
\hline & Timeliness & $\begin{array}{l}\text { Order cycle } \\
\text { consistency }\end{array}$ & $\begin{array}{l}\text { Personnel } \\
\text { quality }\end{array}$ & $\begin{array}{c}\text { Service } \\
\text { quality } \\
\text { consistency }\end{array}$ & $\begin{array}{l}\text { Informatio } \\
\mathrm{n} \text { provision }\end{array}$ & $\begin{array}{l}\text { Order } \\
\text { release } \\
\text { quantity }\end{array}$ \\
\hline $\begin{array}{c}\text { Accuracy of } \\
\text { shipment record }\end{array}$ & 0.829 & 0.260 & 0.032 & 0.102 & 0.173 & 0.071 \\
\hline $\begin{array}{l}\text { Timely delivery of } \\
\text { shipment record }\end{array}$ & 0.801 & 0.292 & 0.053 & 0.040 & 0.314 & 0.120 \\
\hline $\begin{array}{l}\text { Friendliness of } \\
\text { service personnel }\end{array}$ & 0.656 & -0.188 & 0.295 & 0.250 & -0.081 & -0.095 \\
\hline Timely delivery & 0.488 & 0.119 & 0.369 & 0.070 & -0.002 & 0.387 \\
\hline $\begin{array}{l}\text { Consistency of order } \\
\text { cycle }\end{array}$ & 0.126 & 0.858 & 0.122 & -0.096 & 0.172 & 0.038 \\
\hline Average order cycle & 0.439 & 0.665 & -0.200 & 0.217 & 0.006 & 0.009 \\
\hline $\begin{array}{c}\text { Convenient ordering } \\
\text { process }\end{array}$ & 0.487 & 0.496 & 0.452 & -0.127 & -0.136 & 0.028 \\
\hline $\begin{array}{l}\text { Responsiveness to } \\
\text { urgent order }\end{array}$ & 0.128 & 0.380 & 0.188 & 0.210 & 0.172 & 0.270 \\
\hline $\begin{array}{l}\text { Knowledge and } \\
\text { experience of } \\
\text { service personnel }\end{array}$ & 0.085 & -0.021 & 0.764 & 0.066 & 0.319 & 0.094 \\
\hline $\begin{array}{c}\text { Cooperation of } \\
\text { service personnel }\end{array}$ & 0.184 & 0.120 & 0.748 & 0.219 & 0.052 & 0.129 \\
\hline
\end{tabular}




\begin{tabular}{|c|c|c|c|c|c|c|}
\hline Ordering quality & 0.365 & 0.357 & 0.454 & 0.272 & -0.138 & 0.070 \\
\hline $\begin{array}{c}\text { Consistency of } \\
\text { quality }\end{array}$ & 0.156 & -0.042 & 0.155 & 0.809 & 0.169 & 0.173 \\
\hline $\begin{array}{l}\text { Order discrepancy } \\
\text { handling }\end{array}$ & 0.377 & 0.224 & 0.250 & 0.703 & 0.063 & 0.031 \\
\hline Ordering accuracy & 0.031 & 0.467 & 0.471 & 0.533 & 0.100 & -0.103 \\
\hline $\begin{array}{l}\text { Timely information } \\
\text { provision }\end{array}$ & 0.141 & 0.083 & 0.119 & 0.160 & 0.862 & -0.001 \\
\hline $\begin{array}{l}\text { Adequate } \\
\text { information } \\
\text { provision }\end{array}$ & 0.242 & 0.335 & 0.395 & 0.110 & 0.664 & -0.020 \\
\hline $\begin{array}{c}\text { Order release } \\
\text { quantity }\end{array}$ & 0.144 & 0.053 & 0.108 & 0.081 & -0.012 & 0.886 \\
\hline Back order quantity & 0.000 & 0.562 & 0.165 & 0.086 & -0.011 & 0.606 \\
\hline $\begin{array}{l}\text { Rotation sum of } \\
\text { squared loadings }\end{array}$ & 2.901 & 2.622 & 2.388 & 1.807 & 1.563 & 1.478 \\
\hline$\%$ of variance & 16.115 & 14.569 & 13.266 & 10.042 & 8.685 & 8.211 \\
\hline
\end{tabular}

For both cases, standardized factor scores were achieved and each was treated as single scale parameter for further analysis.

\section{Relationship between LSQ and customer satisfaction (H1)}

To test the relationship between LSQ and customer satisfaction, regression analysis was performed. Variable SAT was created by averaging two satisfaction items, and SAT was regressed with five LSQ factor scores. As a result of the analysis, 'service quality consistency' and 'closeness of personnel' was identified as significantly affecting on customer satisfaction (Table 8). The resulting regression model excluded 'timeliness,' 'personnel quality,' and 'order release quantity.' This might happen because there is higher correlation among variables included and excluded in the model. Therefore the result does not mean that those three factors are not important to determine customer satisfaction, rather we can conclude that two factors in the model are the best component to explain customer satisfaction. Based on the result hypothesis 1 was partially supported. 
Table 8

Regression analysis between LSQ and customer satisfaction

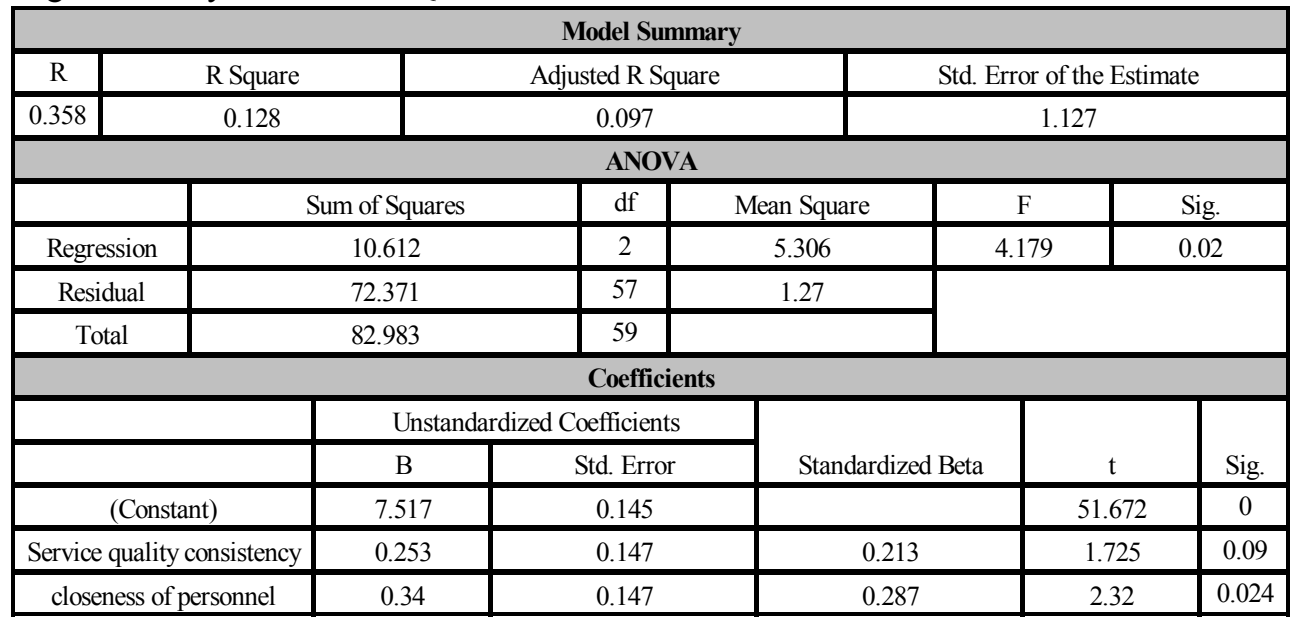

\section{Relationship between LSQ and repurchase intention (H2)}

The relationship between LSQ and repurchase intention was tested with regression analysis. The resulting regression model included two factor variables, 'service quality consistency,' and 'personnel quality,' and excluded 'timeliness,' 'order cycle consistency,' 'order release quantity,' and 'information provision.' This suggested that overall service quality consistency and personnel related factors are more important than other service quality factors, when customers evaluate their intention to repurchase. Therefore, hypothesis 2 was partially supported.

Table 9

Regression analysis between LSQ and repurchase intention

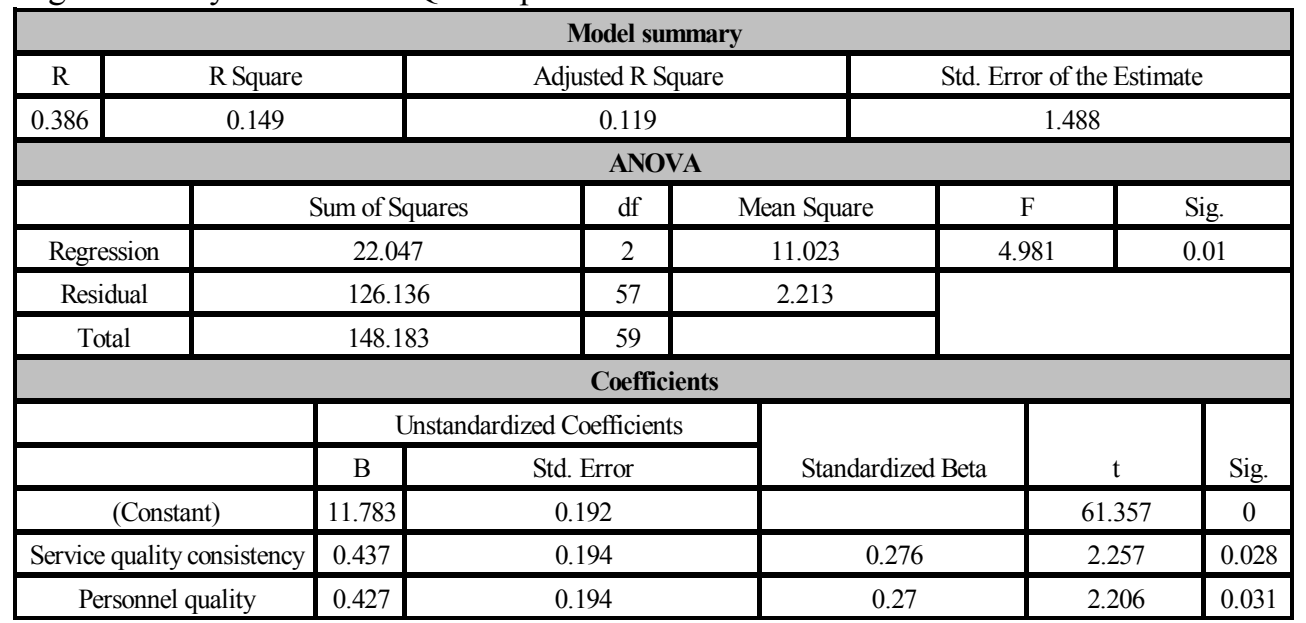




\section{Comparison of LSQ effects on satisfaction and repurchase intention (H3)}

Hypothesis 3 was developed to compare the LSQ factor structure between customer satisfaction and repurchase intention, and also to compare significant influential factors for the two. As shown in Table 6 and 7, factorial structure between the two was slightly different. Especially, 'order cycle consistency' was identified as a distinctive factor for repurchase intention, implying that the length between order and delivery fulfillment was independently considered when customers evaluate their repurchase intention.

In terms of influential factors on satisfaction and repurchase intention, this study identified 'service quality consistency' as a common factor that is important to explain both satisfaction and repurchase intention. This means that the level of consistency of delivered goods/services and the excellence of order discrepancy handling, etc. are core variables that logistics companies might want to focus on to improve both customers' satisfaction and repurchase intention. On the other hand, this study also identified unique influential factors for satisfaction or repurchase intention. For satisfaction, 'closeness of personnel' has a positive effect, whereas 'personnel quality' significantly affects on repurchase intention. This suggests that friendliness of personnel will give a satisfactory transaction experience to customers, which, in turn, will give higher satisfaction to customers.

However, to enhance repurchase intention, friendliness of personnel might not be sufficient; rather knowledge and experience of personnel should be more important factor. Therefore, hypothesis 3 was supported.

\section{Role of company size as moderator (H4)}

The role of company size as a moderator was tested by using independent sample t-test. Before performing t-test, two groups based on the number of employees (small company having less than 50 employees vs. large company having more than 100 employees) were created and used in the analysis. Then independent sample t-test was performed to identify factors discriminate two groups (Table 10). 
Table 10

Independent sample t-test for company size groups about LSQ for satisfaction

\begin{tabular}{|c|c|c|c|c|c|c|c|c|}
\hline & Groups & $\mathrm{N}$ & Mean & $\mathrm{t}$ & $\mathrm{df}$ & Sig. (2-tailed) & Mean Difference & $\begin{array}{l}\text { Std. Error } \\
\text { Difference }\end{array}$ \\
\hline \multirow{2}{*}{ Timeliness } & Small & 18 & 0.072 & \multirow{2}{*}{0.431} & \multirow{2}{*}{55} & \multirow{2}{*}{0.668} & \multirow{2}{*}{0.126} & \multirow{2}{*}{0.293} \\
\hline & Large & 39 & -0.054 & & & & & \\
\hline Service & Small & 18 & 0.195 & \multirow{2}{*}{1.124} & \multirow{2}{*}{55} & \multirow{2}{*}{0.266} & \multirow{2}{*}{0.325} & \multirow{2}{*}{0.289} \\
\hline $\begin{array}{c}\text { quality } \\
\text { consistency }\end{array}$ & Large & 39 & -0.130 & & & & & \\
\hline Closeness & Small & 18 & 0.540 & \multirow{2}{*}{2.883} & \multirow{2}{*}{55} & \multirow{2}{*}{0.006} & \multirow{2}{*}{0.788} & \multirow{2}{*}{0.273} \\
\hline $\begin{array}{c}\text { with } \\
\text { personnel }\end{array}$ & Large & 39 & -0.249 & & & & & \\
\hline \multirow{2}{*}{$\begin{array}{c}\text { Personnel } \\
\text { quality }\end{array}$} & Small & 18 & 0.151 & \multirow{2}{*}{0.913} & \multirow{2}{*}{55} & \multirow{2}{*}{0.365} & \multirow{2}{*}{0.259} & \multirow{2}{*}{0.283} \\
\hline & Large & 39 & -0.108 & & & & & \\
\hline \multirow{2}{*}{$\begin{array}{c}\text { Order release } \\
\text { quantity }\end{array}$} & Small & 18 & -0.313 & \multirow{2}{*}{-1.690} & \multirow{2}{*}{55} & \multirow{2}{*}{0.097} & \multirow{2}{*}{-0.483} & \multirow{2}{*}{0.286} \\
\hline & Large & 39 & 0.170 & & & & & \\
\hline
\end{tabular}

As shown in Table 10, two LSQ factors for satisfaction, 'closeness with personnel' and 'order release quantity' were identified as discriminating company size groups. Specifically, small group evaluated 'closeness with personnel' highly important for their satisfaction, compared to large group's evaluation. In reverse, large group evaluated 'order release quantity' much more important for their satisfaction than small group did. This suggested that there are different perceptions on important LSQ factors depending on company size, supporting hypothesis 4.

\section{Relationship between customer satisfaction and repurchase intention (H5)}

The relationship between satisfaction and repurchase intention was tested by using simple linear regression between the two (Table 11). 
Table 11

Regression analysis between customer satisfaction and repurchase intention

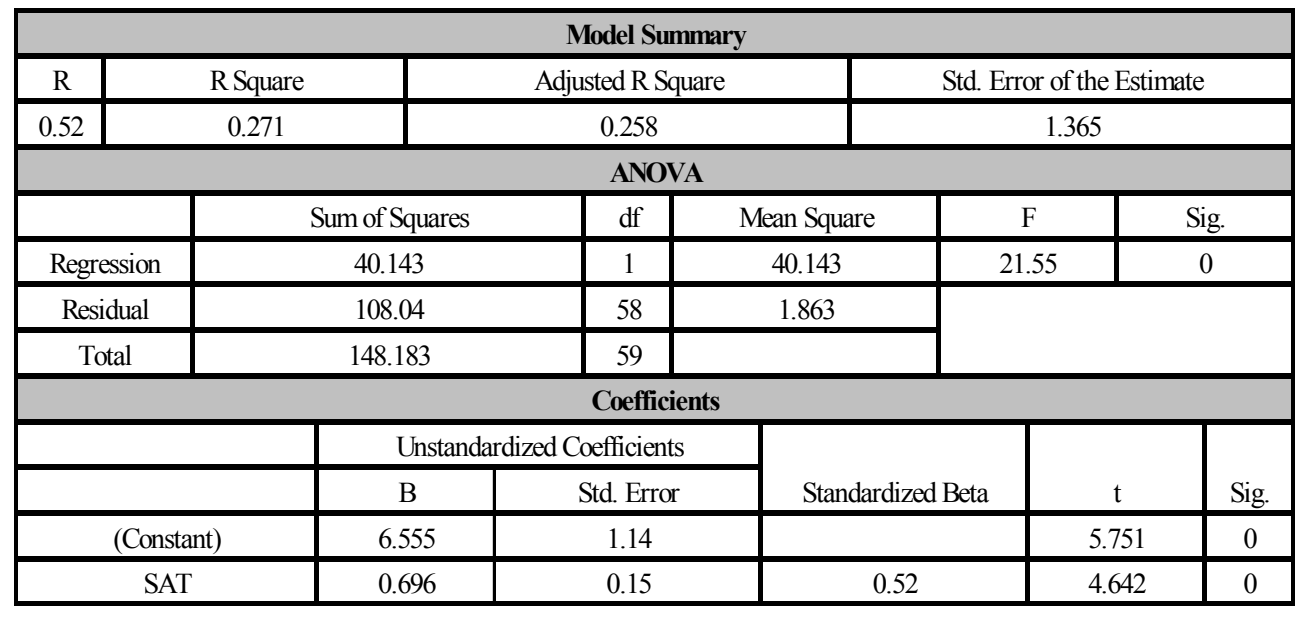

As shown in Table 11, customer satisfaction has a strong positive linear relationship with repurchase intention. In other words, satisfied customers are highly likely repurchase. Considering that satisfaction and repurchase intention are not necessarily go together in industrial market, this finding is meaningful to treat customer satisfaction as an antecedent of customers' repurchase behavior in industrial market. Consequently, hypothesis 5 was supported.

\section{Conclusion}

The importance of logistics service has been greatly emphasized; however, more detailed investigation about which kind of logistics service would lead customer satisfaction and their repurchase behavior has been limited. In this regard, the findings from this study have following implications.

First of all, for the customers who have strong and stable relationships, logistics companies should focus more on delivery fulfillment and qualified ordering process. Also considering the characteristics of industrial buyer-seller that the relationship tends to be longer, logistics service personnel should be able to contact customers regularly to enhance personal friendliness in the relationship.

For short term customers who do not have stable relationships, logistics service providers should focus more on personnel quality and consistency of service quality to increase repurchase intention. In specific, customer service operators should be trained frequently to update their knowledge and to elaborate their experience. To observe the consistency of service quality, service operators should keep track on customers' complaint and dissatisfaction issues, and then reflect those on the next order process. 
Third, this study identified five logistics service quality factors in relation to customer satisfaction, and six logistics service quality factors in relation to repurchase intention. Based on the close look at those factors, 'timeliness,' 'service quality consistency,' 'personnel quality,' and 'order release quantity' are common factors for both satisfaction and repurchase intention. This implies that those four factors are the core of the logistics service and the most important factors to improve business performance.

\section{Acknowledgement}

This work was supported by Inha University Research Grant 36118-01.

\section{References}

Geva, A. and A. Goldman. 1999. Duality in consumer post-purchase attitude. Journal of Economic Psychology. 12(1): 141-164.

Heinritz, S. F. and P. V. Farell. 1971. Purchasing Principle and Applications. 5th ed., Englewood Cliffs, N. J. : Prentice-Hall Inc.

Lambert, Douglas M. 1976. The Development of an Inventory Costing Methology: A Study of the Costs Associated with Holding Inventory. Chicago: National Council of Physical Distribution Management.

Lele, M. and J.N. Sheth. 1991. The Custome is Key Gaining and Unbeatable Advantage through Customer Satisfaction. New York: John Willey \& Sons, Inc.

Mentzer J. T., D.J. Flint, and J.L. Kent. 1999. Developing a logistics service quality scale. Journal of Business Logistics. 20(1):9-32.

Mentzer, J.T., J. F. Daniel, and G.M.T. Hult. 2001. Logistics service quality as a segmentcustomized process. Journal of Marketing. 65(4): 82-104

Oliver, R. L. 1980. A cognitive model of the antecedents and consequences of satisfaction decision. Journal of Marketing. 17(4): 460-469.

Rust, R. T. and A. J. Jahorik. 1993. Customer satisfaction, customer retention, and market sShare. Journal of Retailing. 69(2): 193-215

Wang, F., M. Head, and N. Archer. 2000. A Relationship-building model for Web retail marketplace. Electronics Networking Applications and Policy. 10(5): 374-384. 